\title{
Purification and characterization of cellulase from Aspergillus unguis isolated from decaying coconut wood
}

\section{Mohanappriya Shanmugarajah and Ranganathan Kapilan*}

\author{
Department of Botany, University of Jaffna, Jaffna, Sri Lanka
}

\begin{abstract}
The insufficiency of available natural fossil fuels for increasing human population, air pollution due to partial combustion of fossil fuel and the release of greenhouse gasses have led great attention on the usage of cellulase like enzymes to hydrolyze lignocellulosic substances to produce bioethanol. Thermostability and kinetic properties of cellulases need to be studied before deciding the eligibility of the enzymes for their potential applications. This study was aimed to purify the crude cellulase from Aspergillus unguis and to characterize the purified cellulase. When the crude enzyme from Aspergillus unguis isolated from decaying coconut wood, was subjected to fractional precipitation and dialysis by the addition of $80 \%$ saturated $\left(\mathrm{NH}_{4}\right)_{2} \mathrm{SO}_{4}$, the recovery of cellulase was $83.9 \%$ showing specific activity of $16386.43 \mathrm{Umg}^{-1}$ protein. The dialyzed enzyme was added to a column packed with DEAE-Sepharose equilibrated with 0.01M sodium phosphate buffer ( $\mathrm{pH}$ 7.0) and unbound proteins were washed with the same buffer. The specific activity of cellulase was increased from 3228 to $37071 \mathrm{Umg}^{-}$ ${ }^{1}$ protein, which was 11.5-fold higher than that of the crude cellulase with $67.6 \%$ yield. The molecular weight of the purified cellulase was determined as $50 \mathrm{KDa}$ using Poly Acrylamide Gel Electrophoresis (SDS-PAGE). When the activity of purified cellulase was measured at different temperatures ranging from $40^{\circ} \mathrm{C}$ to $90^{\circ} \mathrm{C}$ at neutral $\mathrm{pH}$, the optimum temperature for the activity of the purified cellulase enzyme was $70^{\circ} \mathrm{C}$. The $\mathrm{pH}$ was optimized as 5.0 for the cellulase at $70^{\circ} \mathrm{C}$. Michaelis constant for the purified cellulase to soluble cellulose by Lineweaver-Burk Plot was $4.45 \times 10^{-2}$ moldm $^{-3}$ and $V_{\text {max }}$ was $28.5714 \mathrm{mgml}^{-2} \mathrm{mins}^{-1}$ with $10 \mathrm{gL}^{-}$ ${ }^{1}$ of cellulose substrate, at $\mathrm{pH} 5.0$ and $70^{\circ} \mathrm{C}$. The purified cellulase was stable for at least 90 minutes at $\mathrm{pH} 5.0$ and $70^{\circ} \mathrm{C}$ and the half-life obtained for this enzyme was significantly higher at $70^{\circ} \mathrm{C}$ than any other temperatures. Therefore, the crude cellulase from Aspergillus unguis can be purified by ammonium sulphate precipitation and DEAE-sepharose ion exchange chromatography. The thermostable acidic cellulase from Aspergillus unguis could be a potential candidate for diverse industrial applications.
\end{abstract}

Key words: Aspergillus unguis, cellulase, kinetic properties, michaelis constant, purification.

\section{INTRODUCTION}

Bioconversion of lignocellulosic materials into efficient bioactive products is the principle step to establish a vigorous biological economy. This process needs an initial pretreatment step followed by an enzyme hydrolysis to produce fermentable sugars. Ionic liquid pretreatment is a highly advanced method to induce the biomass saccharification by cellulase enzyme. Major disadvantage of this method is that the remaining ionic liquid in the hydrolysis

*Corresponding author: ranganat@ualberta.ca

Received: 17.06.2020 buffer will hinder the cellulase activity. Efficient enzyme hydrolysis will overcome the recalcitrance of lignocellulosic biomass to produce fermentable sugars. The industrialization process of the cellulase production through pretreatment and hydrolysis, involves in major cost reduction and utilization of maximum resources (Juturu and $\mathrm{Wu}, 2014$ ). Currently cellulases have created considerable attention and the demand for the production has been showing an increasing trend because of their usage in diverse industries such as 
food, textiles, pulp and paper and agriculture and land use (Costa et al., 2008). Increasing rate of greenhouse gas emission due to substantial incidences of partial burning of fossil fuel have resulted in the usage of cellulases for the hydrolysis of the lignocellulosic waste materials for producing bioethanol (Zaldivar et al., 2001). Cellulases consist of three different enzymes such as endo-1,4- $\beta$-glucanase (Endogluconase), exo-1,4- $\beta$-glucanase (Exoglucanases) and $\beta$-glucosidase. These enzyme combinations hydrolyze the cellulose substrate into soluble sugars and glucose (Lynd et al., 2002). Crystalline macroscopic structure of cellulose will be broken down by endogluconases and results in short linear chains of glucose molecules. Exo-glucanases will react on the broken pieces of short chains and this would yield cellobiose and glucose. Saccharification by $\beta$-glucosidases will break cellobiose and small cellooligosaccharides into basic glucose molecules (Harrison et al., 1998). Cellulase production could be induced by microorganisms when they grow on appropriate cellulosic materials under condusive environmental conditions. Different types of cellulases are produced by major microorganisms classified under fungi, bacteria and actinomycetes (Gaur \& Tiwari, 2015).

Multicellular fungal decomposers have been substantially used for breaking down cellulosic materials all around the globe (Moore Landecker, 1996). These fungi can grow well on diverse wood types and the growth of the fungi has been extremely high during the natural degradation of wood components. Members of the ascomycota, basidiomycota, and deuteromycota are considered as efficient fungal decomposers. The cellulolytic fungul species include Aspergillus, Fusarium, Penicillium, Trichoderma, Alternaria etc. (Mehrotra and Aneja, 1990). The fungal cellulases produced by Aspergillus, Trichoderma,Penicillium and Sclerotium are of higher importance for the industrial applications because of their capacity to produce comparatively substantial quantities of cellulases and their extracellular and adaptive nature in diverse environmental conditions (Mathew et al., 2008). Trichoderma reesei has been reported as one of the best native cellulose hydrolyzers (Singhania et al., 2006).

Thermophilic fungi are highly preferred for cellulase extraction because of the swelling up of cellulose fibers at higher temperatures would facilitate the easy extraction of the hydrolytic enzymes (Li et al., 2011). Thermophilic fungus Talaromyces emersonii produced active cellulase at $70^{\circ} \mathrm{C}$ (Murray et al., 2004). Two strains of Penicillium that were isolated from soil of subtropical region produced functional extracellular cellulase enzymes (Picart et al., 2007). Thermostable cellulases are produced in high phase by organisms such as Chaetomium thermophilum, Sporotrichum thermophile, Talaromyces emersonii and Thermoascus aurantiacus (Li et al., 2011). Extracellular thermostable cellulases are potentially useful in the biotechnological and industrial applications since they play vital role in the bioconversion of cellulosic biomass to different value-added biomaterials. Therefore, the objective of this study was to purify the crude cellulase from Aspergillus unguis and to determine the kinetic properties and stability of the purified cellulase.

\section{MATERIALS AND METHODS}

\section{Microorganism}

Among the different types of fungal colonies isolated from different lignocellulosic materials, colonies that produced higher quantity of cellulase enzyme were cultured initially. The best cellulase producer, isolated from decaying coconut wood was identified as Aspergillus unguis and used in this study. 


\section{Chemicals and Media}

All the chemicals used here were from standard sources. The activation medium contained cellulose $0.4 \mathrm{~g}$ and nutrient broth $0.8 \mathrm{~g}$ in $100 \mathrm{ml}$ of distilled water. Fermentation medium contained $\left(\mathrm{gL}^{-1}\right)$ cellulose $2.0 \mathrm{~g}$; carboxymethyl cellulose $0.3 \mathrm{~g}$; ammonium sulphate $0.3 \mathrm{~g}$ and incubated at room temperature $\left(27^{\circ} \mathrm{C}\right), \mathrm{pH}$ 7.0 and $100 \mathrm{rpm}$ for 6 days.

\section{Purification of cellulase}

To the fermentation medium, $24 \mathrm{~h}$ old cultures of Aspergillus inoculum (size $6 \times 10^{6}$ conidia) was added and incubated at $30^{\circ} \mathrm{C}$ in an orbital shaker (at 100rpm). Samples were removed from the shaker after 6 days and centrifuged and the supernatant was used as the cellulase source and subjected for purification.

The crude culture filtrate was cool centrifuged at $10,000 \mathrm{rpm}$ to remove the cells and the residual medium. Supernatant was precipitated overnight with $\left(\mathrm{NH}_{4}\right)_{2} \mathrm{SO}_{4}$ (80\% saturation) and the pellet was recovered by centrifugation at $12000 \mathrm{rpm}$ for $10 \mathrm{~min}$. The pellet was re-suspended in a small amount $100 \mathrm{mM}$ phosphate buffer ( $\mathrm{pH}$ 7.0) and dialyzed overnight with $80 \%$ saturated $\left(\mathrm{NH}_{4}\right)_{2} \mathrm{SO}_{4}$ against the same buffer. The corresponding precipitates were recovered, dissolved individually in buffer and assayed for both total protein content and cellulase activity. The dialyzed sample was loaded to a DEAE-Sepharose (SigmaAldrich, USA) column equilibrated with sodium phosphate buffer $(100 \mathrm{mM}$, $\mathrm{pH} 7.0)$.

The enzyme fraction was allowed to bind with matrix for $2 \mathrm{~h}$ at $4^{\circ} \mathrm{C}$. The unbound fraction was collected and analyzed for the cellulase enzyme activity and for protein content. The bound fractions were eluted with a $\mathrm{NaCl}$ gradient $(0.1-0.5 \mathrm{M}, 10 \mathrm{ml}$ each) in the same buffer at a regular flow rate of $1.0 \mathrm{ml} \mathrm{min}$.

\section{Polyacrylamide gel electrophoresis}

The active fraction, showing higher specific activity, collected from the Sepharose column filtration was electrophorized by Sodium Dodecyl Sulphate-Poly Acrylamide gel electrophoresis with $12.5 \%$ polyacrylamide gel (Kapilan and Arasaratnam, 2014). The molecular weight of the cellulase was estimated by SDSPAGE against the molecular mass markers that ran with the samples.

\section{Kinetic studies}

\section{Activity of cellulase with time}

Soluble cellulose $\left(1 \mathrm{gml}^{-1} 0.25 \mathrm{ml}, \mathrm{pH} 5.0\right)$ was mixed with purified cellulase $(0.25 \mathrm{~mL})$ at $70^{\circ} \mathrm{C}$ in triplicates and the amount of glucose produced was monitored. Activity of the purified cellulase was determined as a function of time with soluble cellulose.

\section{Effect of temperature}

The effect of temperature on cellulase activity was determined by incubating the appropriately diluted (10 fold dilution) cellulase enzyme ( $\mathrm{pH}$ 5.0) for 5 minutes with $0.25 \mathrm{~mL}$ of soluble cellulose at $\mathrm{pH} 7.0$, $10 \mathrm{ml}(1 \mathrm{~g} / 100 \mathrm{ml})$ and at different temperatures such as $40^{\circ} \mathrm{C}, 45^{\circ} \mathrm{C}, 50^{\circ} \mathrm{C}$, $55^{\circ} \mathrm{C}, \quad 60^{\circ} \mathrm{C}, \quad 65^{\circ} \mathrm{C}, \quad 70^{\circ} \mathrm{C}, \quad 75^{\circ} \mathrm{C}$ in triplicates. The enzyme and substrate samples at $\mathrm{pH} 7.0$ were preincubated at the respective temperatures considered for the studies for 5 minutes and then mixed to determine the activities.

\section{Effect of pH}

The effect of $\mathrm{pH}$ on cellulase activity was measured by preparing $1 \mathrm{~g} / 100 \mathrm{ml}$ soluble cellulose in phosphate buffers at different $\mathrm{pH}$ values ranging from 2.0 to 8.0 in triplicates and incubated at $70^{\circ} \mathrm{C}$. The enzyme and substrate samples at respective $\mathrm{pH}$ values were preincubated at $70^{\circ} \mathrm{C}$ for 5 minutes. 


\section{Effect of substrate concentration}

Different concentrations of cellulose solutions were prepared $(0.25$ to $40 \mathrm{gL}-1)$ in citrate -phosphate buffer at optimum $\mathrm{pH}$ in triplicates and they were allowed to react with the diluted enzyme at optimum temperature for optimized time. The enzyme activity was measured. The Michelis constant and $\mathrm{V}_{\max }$ for the cellulase to cellulose were calculated by plotting Lineweaver-Burk graph.

\section{Effect of temperature on the stability of cellulase}

Stability of the purified cellulase preparations was determined, at the optimum $\mathrm{pH}$ (5.0) by incubating the enzyme at different temperatures such as $60^{\circ} \mathrm{C}, \quad 70^{\circ} \mathrm{C}$ and $80^{\circ} \mathrm{C}$. The enzyme activities were assayed under optimized conditions.

\section{Analytical methods}

Cellulase activities were assayed according to the modified method described by Ghose (1987). The glucose produced was measured by Dinitro salicylic acid (DNSA) method. One unit of cellulase activity is defined as the amount of enzyme that produces one $\mu \mathrm{mol}$ of reducing sugar in one minute at $\mathrm{pH} 5.0$ and $50^{\circ} \mathrm{C}$ with $10 \mathrm{ml}$ $(1 \mathrm{~g} / 100 \mathrm{ml})$ cellulose.

The values of enzymatic activity were expressed as $\mathrm{U} / \mathrm{ml}$. Reducing sugar was measured by DNS method (Miller, 1959).

Protein concentration was determined by Lowry's method (Lowry et al., 1951). Each experiment was performed in triplicate and the mean and standard deviation for each experiment were presented.

\section{Statistical analysis}

All the experiments were made in triplicates and the mean values were used to plot the graphical representation. Statistical analyses were performed using R 2.15.3 (R
Development Core Team, 2010). The data were analyzed using ANOVA. Tukey's multiple comparison test was used to determine the significant differences at $\mathrm{p} \leq$ 0.05 .

\section{RESULTS AND DISCUSSION}

\section{Purification of cellulase}

When the crude enzyme was precipitated by fractional precipitation method by the addition of solid $\left(\mathrm{NH}_{4}\right)_{2} \mathrm{SO}_{4}$ from 10 to 90\% saturation, highest specific activity (36.5 $\mathrm{Umg}^{-1}$ protein) was precipitated at $80 \%$ solid $\left(\mathrm{NH}_{4}\right)_{2} \mathrm{SO}_{4}$ saturation. The protein precipitated with $80 \%$ saturation of $\left(\mathrm{NH}_{4}\right)_{2} \mathrm{SO}_{4}$ was collected and dissolved in sodium phosphate buffer ( $\mathrm{pH}$ 7.0) and dialyzed against the same buffer. This fraction had $16386.43 \mathrm{U} \mathrm{mg}^{-1}$ of specific activity with the recovery of $83.8 \%$ and the purification fold for this step was 5.08 (Table 1). When the active fraction of ammonium sulphate was subjected for further purification by using DEAESepharose ion exchange chromatography and the dialyzed enzyme was added to a column packed with DEAE-Sepharose equilibrated with $0.01 \mathrm{M}$ Sodium phosphate buffer ( $\mathrm{pH} 7.0)$ the specific activity of cellulase was increased from 3228 to 16386 $\mathrm{Umg}^{-1}$ protein, which was 11.5 fold higher than that of the crude cellulase with $67.6 \%$ yield.

One $\mathrm{mL}$ of sample was loaded into the DEAE-Sepharose column pre-equilibrated with sodium phosphate buffer $(100 \mathrm{mM}$ at $\mathrm{pH}$ 7.0) and allowed to travel through the column. When the un-bound fraction was collected and analyzed for cellulase enzyme activity and protein content, the cellulase activity was absent in the unbound fraction but protein was estimated as $1.78 \mathrm{mg} \mathrm{ml}^{-1}$. Absence of enzyme activity in the un-bound fraction lead to a finding that the total cellulase present was bound to the matrix. When the bound cellulase enzyme was eluted by sodium phosphate buffer (100 mM, pH 7.0) having $\mathrm{NaCl}$ with 
increasing concentration gradient $(0.1 \mathrm{M}$ to $1.0 \mathrm{M}, 10 \mathrm{ml}$ of $\mathrm{NaCl}$ solution of each concentration), the cellulase enzyme activity was detected in the small fraction released by the addition of $0.5 \mathrm{M} \mathrm{NaCl}$. One prominent peak was observed at the $20^{\text {th }}$ fraction (Figure 1 ).

\section{Separation of purified cellulase on SDS- PAGE and determination of the molecular weight}

When the pooled purified cellulase mix was run in the gel electrophoresis and stained with ethidium bromide, the sample gave a very clear single band (Figure 2). The molecular weight of the purified cellulase was determined by the method developed by Weber and Osborn (1969). The distance traveled by molecular markers and purified cellulase were measured. The linear relationship existed between the logarithm of molecular weight of molecular markers and distance migrated by molecular markers. The molecular weight of the purified cellulase was estimated as $50 \mathrm{kDa}$.

Table 1: Purification profile of cellulase enzyme from Aspergillus unguis on ammonium sulphate and Sepharose anion-exchange chromatography.

\begin{tabular}{lcrrrr}
\hline \multicolumn{1}{c}{ Purification steps } & $\begin{array}{c}\text { Total } \\
\text { activity } \\
(\mathbf{U})\end{array}$ & $\begin{array}{c}\text { Total } \\
\text { protein } \\
(\mathbf{m g})\end{array}$ & $\begin{array}{c}\text { Specific } \\
\text { activity }\end{array}$ & $\begin{array}{c}\text { Yield } \\
(\mathbf{\%})\end{array}$ & $\begin{array}{c}\text { Purification } \\
\text { fold }\end{array}$ \\
& 381788 & 118.25 & 3228.65 & 100 & 1.00 \\
\hline Crude enzyme & 320191 & 19.54 & 16386.43 & 83.87 & 5.08 \\
Ammonium sulphate addition & & & & & \\
Sepharose anion-exchange & 258012 & 6.96 & 37070.75 & 67.58 & 11.48 \\
chromatography & & & &
\end{tabular}

Note: Specific activity was calculated dividing the total activity by total protein at a particular purification step. Purification fold was calculated dividing the specific activity of a particular purification step, by specific activity of crude enzyme sample.
Recovery (\%) was calculated dividing the total enzyme activity of a particular purification step by total enzyme activity of crude enzyme sample and multiplied by 100. 


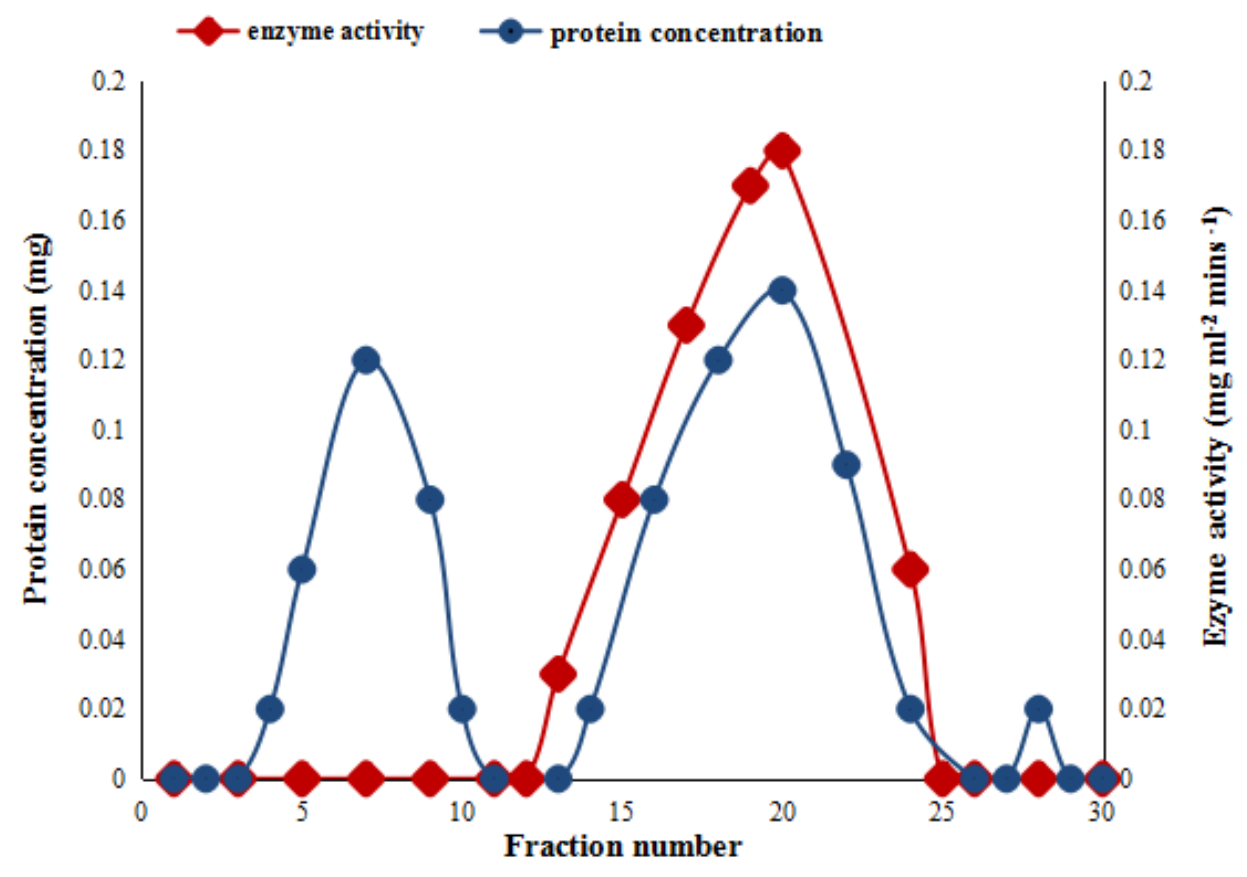

Figure 1: Purification profile of the cellulase of Aspergillus unguis using ammonium sulphate and Sepharose anion-exchange chromatography C- 25 fast flow column $(1.5 \times 25 \mathrm{~cm}) .(\bullet)$, cellulase activity $\left(\mathrm{UmL}^{-1}\right)$ eluted with $0.8 \mathrm{M} \mathrm{NaCl}$ containing $0.01 \mathrm{M}$ phosphate buffer $(\mathrm{pH} 7.0)$; $(\boldsymbol{\Delta})$, Protein $(\mathrm{mg})$ eluted with $0.8 \mathrm{M} \mathrm{NaCl}$ containing $0.01 \mathrm{M}$ phosphate buffer $(\mathrm{pH} 7.0)$ were used at flow rate of $1 \mathrm{mLmin}^{-1}$ to wash the unbound protein.

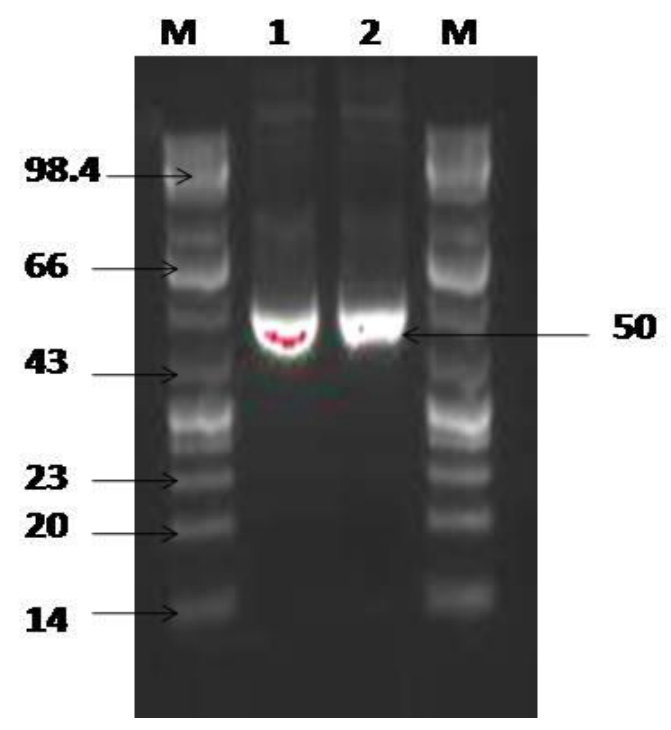

Figure 2: SDS-PAGE of different fractions of cellulase of Aspergillus unguis obtained in the purification. Lane 1: Marker; lane 1: Concentrated cellulose enzyme after ammonium sulphate precipitation lane 2: Purified cellulase enzyme after gel-filtration chromatography. Molecular weights are mentioned in $\mathrm{kDa}$. 


\section{Activity of cellulase with time}

Purified cellulase of the triplicate samples showed zero order kinetics for 5 minutes. Therefore, the incubation time for the kinetic studies was fixed as 05 minutes for further experiments.

\section{Effect of temperature}

When the cellulolytic activity was assayed at different temperatures ranging from $40^{\circ} \mathrm{C}-90^{\circ} \mathrm{C}$ at $\mathrm{pH} 7.0$, significantly higher activity was obtained at $70^{\circ} \mathrm{C}(17.1052 \mathrm{mg}$ $\mathrm{ml}^{-2}$ mins $^{-1}$, (Figure 3)) than the other temperatures tested $(\mathrm{p}=>0.05)$.

\section{Effect of pH}

When the initial $\mathrm{pH}$ of the media was changed, significantly higher cellulase activity was obtained at $\mathrm{pH} 5.0$ than the other $\mathrm{pH}$ values tested (4.0 to 8.0, Figure 4). Cellulase activity was observed in all media maintained at different $\mathrm{pH}$ values. Since significantly higher activity was obtained at $\mathrm{pH}$ 5.0, this $\mathrm{pH}$ value was chosen for further studies.

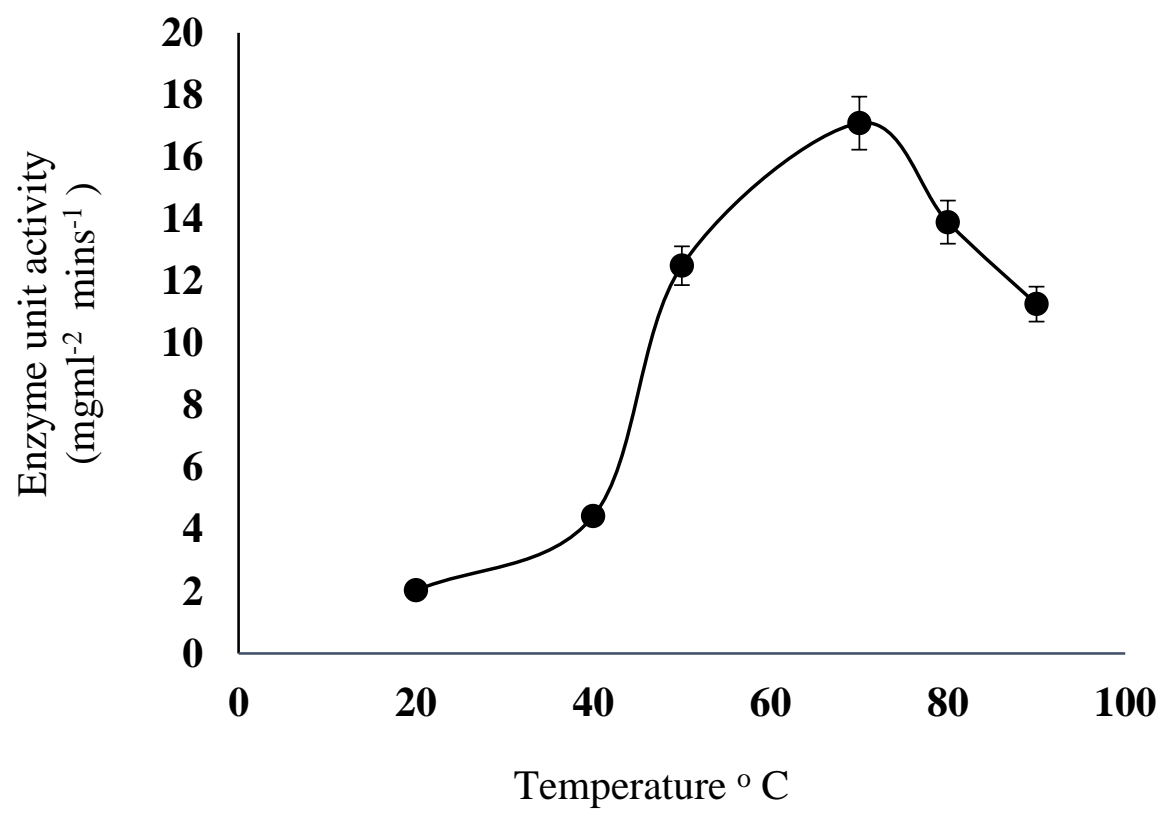

Figure 3: Effect of temperature in purified cellulase enzyme activity of Aspergillus unguis obtained from decaying coconut wood. 


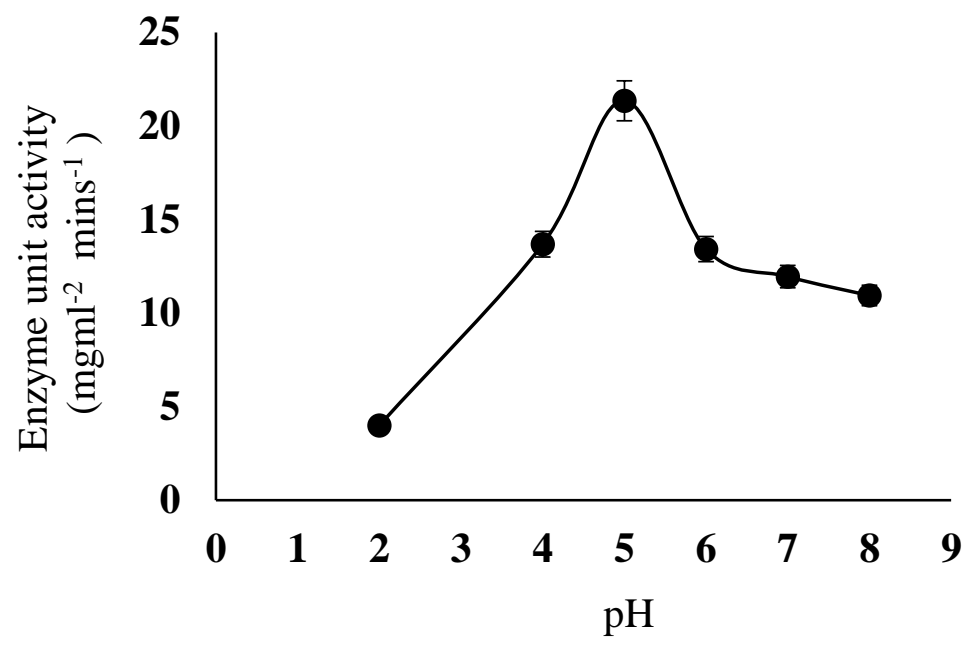

Figure 4: Effect of $\mathrm{pH}$ of the media on the purified cellulase of Aspergillus unguis obtained from decaying coconut wood.

\section{Effect of substrate concentration}

When the cellulose concentration was increased from 0.25 to $40 \mathrm{gL}^{-1}$ at $\mathrm{pH} 5.0$ and $70^{\circ} \mathrm{C}$, the cellulase activities obtained beyond the concentration of $10 \mathrm{gL}^{-1}$ were significantly higher than all the other lower concentrations tested (Figure 5). Therefore $10 \mathrm{gL}^{-1}$ was fixed as the cellulose concentration for all the future experiments. Michaelis constant for the purified cellulase enzyme to soluble cellulose by Lineweaver-Burk Plot was $4.45 \times 10^{-}$ ${ }^{2}$ moldm $^{-3}$ and Vmax was $28.5714 \mathrm{mg} \mathrm{ml}^{-}$ ${ }^{2} \mathrm{mins}^{-1}$ at $\mathrm{PH} 5.0$ and at $70^{\circ} \mathrm{C}$ (Figure 6). Therefore $10 \mathrm{ml}(1 \mathrm{~g} / 100 \mathrm{ml})$ substrate was used for the purified cellulase enzyme assay.

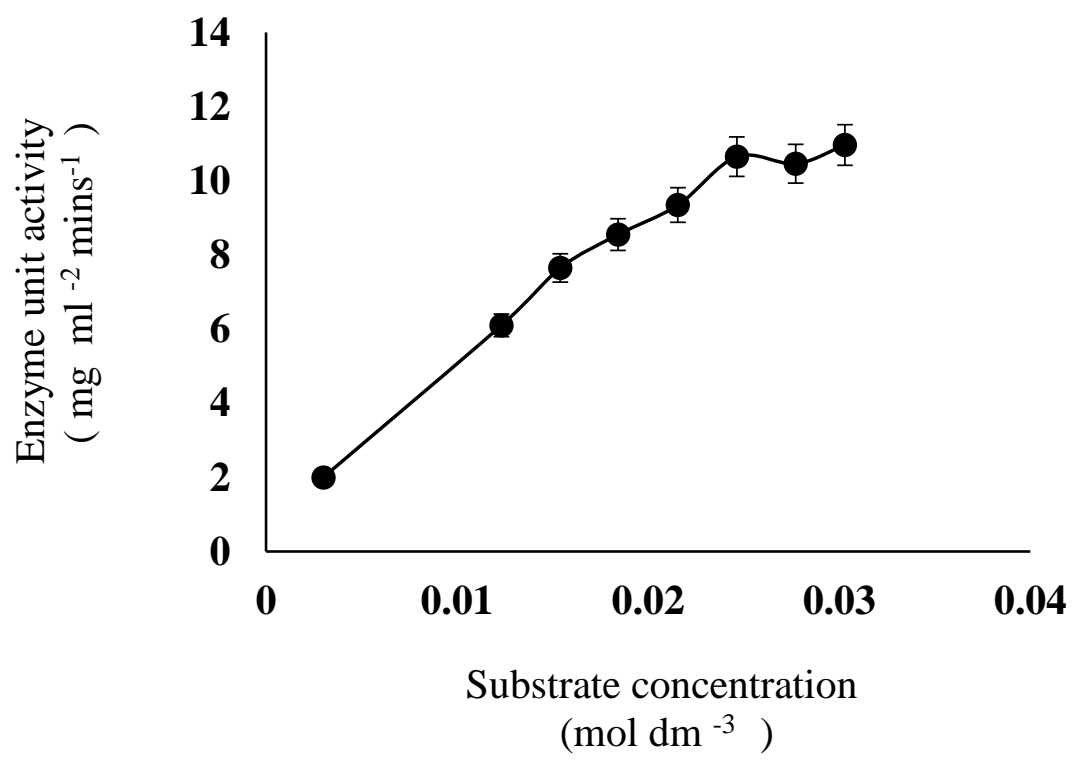

Figure 5: Effect of different substrate concentration on the purified cellulase enzyme of Aspergillus unguis isolated from coconut wood. 
Effect of temperature on the stability of cellulase

When the purified cellulase was preincubated at different temperatures $(60,70$ and $80^{\circ} \mathrm{C}$ ) for a period of 100 minutes, the activity significantly decreased with time. The enzyme was stable for at least forty minutes at all the temperatures tested. When the purified enzyme was preincubated at $70^{\circ} \mathrm{C}$ for 60 minutes, more than $70 \%$ of the mean original activity was retained. When the purified enzyme was pre-incubated at $70^{\circ} \mathrm{C}, 95 \%$ of the mean original activity was retained at $20 \mathrm{~min}$, while at $90 \mathrm{~min}, 18 \%$ of the mean original activity was retained. After 80 minutes of incubation, the half-life of the purified cellulase was $32 \mathrm{mins}$ and $19 \mathrm{sec}$ when cellulase was incubated at $70^{\circ} \mathrm{C}$ (Figure 7). When the purified cellulase was preincubated at $70^{\circ} \mathrm{C}$ for one hour, $25.5 \%$ of the mean original activity was retained and this activity was significantly higher than that of $60^{\circ} \mathrm{C}$ and $80^{\circ} \mathrm{C}$.

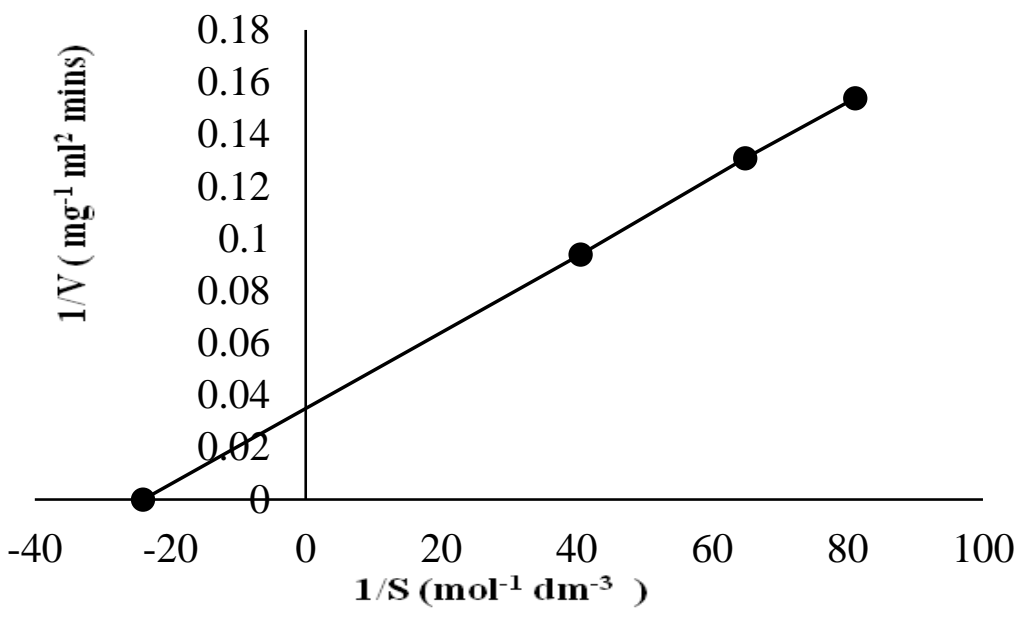

Figure 6: Lineweaver-Burk plot of the purified cellulase from Aspergillus unguis at pH 5.0 and $70^{\circ} \mathrm{C}$ using different concentrations of cellulose substrate

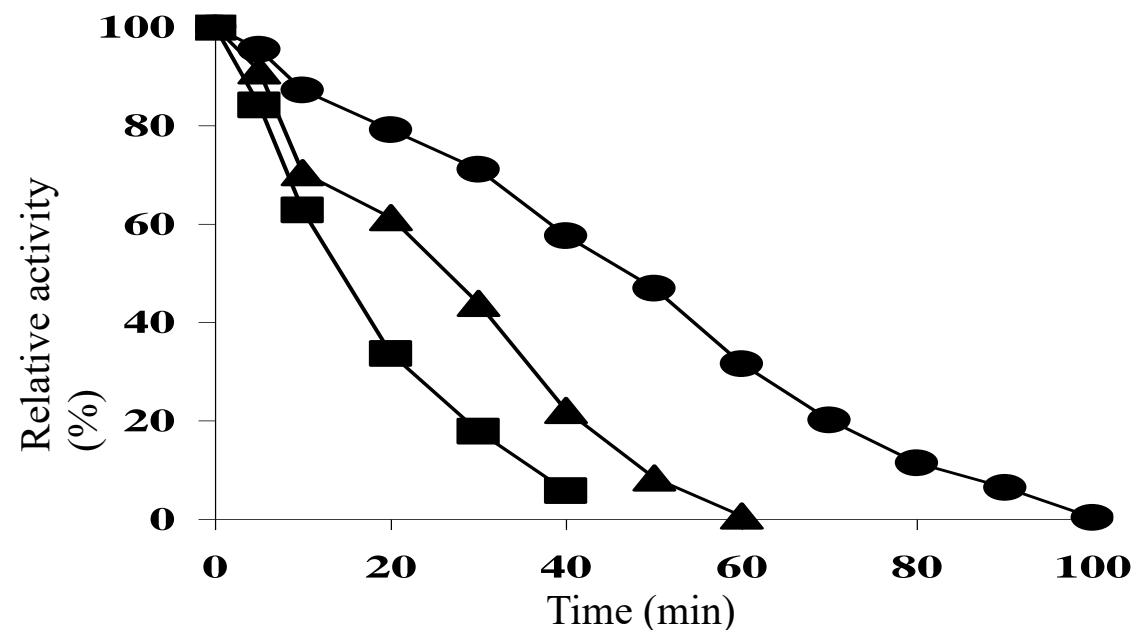

Figure 7: Stability of purified cellulase of Aspergillus unguis at different temperatures of $(\boldsymbol{\Delta})$, $60 ;(\bullet), 70$ and $(\bullet), 80$ at $\mathrm{pH} 50^{\circ} \mathrm{C}$ with $10 \mathrm{gL}^{-1}$ cellulose $(0.01 \mathrm{M}$ phosphate buffer $)$ at $\mathrm{pH} 5.0$. 
Fungal species that can produce diverse lignocellulolytic enzymes play vital role in the bioremediation, biogeochemical cycles and nature's balance. This study was targeted on the purification and characterization of extracellular cellulase enzyme produced by Aspergillus unguis after being grown in fermentation medium for 6 days at $100 \mathrm{rpm}$. The crude cellulase enzyme from Aspergillus unguis was purified from the spent medium by $80 \%$ saturated ammonium sulphate precipitation and by ion exchange chromatography using DEAE-sepharose fast flow and the molecular weight was determined as 50 KDa using SDS-PAGE. The cellulase enzyme from Bacillus vallismortis RG-07 was purified by $\left(\mathrm{NH}_{4}\right)_{2} \mathrm{SO}_{4}$ precipitation, ion exchange and gel filtration chromatography and the final recovery was $28.8 \%$. Using the SDS-PAGE and activity gel analysis the molecular weight of purified cellulase from thermostable alkalophilic cellulase Bacillus vallismortis RG-07 was determined as 80 kDa (Gaur \& Tiwari, 2015).

Different cellulases were separated and purified from fungal species Aspergillus nidulans based on the affinity of the enzyme towards substrate and the molecular weights were recorded for various enzyme forms as Exo-I, 29000; Exo-II, 72500; Exo-III, 138000; Endo-I, 25000; Endo-II, 32500; $\beta$-Gluco-I, 14000 and $\beta$-Gluco-II, 26000 (Bagga et al., 1990). When purified cellulase from Aspergillus unguis was subjected for the gel electrophoresis run, there was a very clear single band. This single band proved that Aspergillus unguis produces only one type of cellulase enzyme. The molecular weight of the purified cellulase was $50 \mathrm{kDa}$. The molecular weight of this purified cellulase is closely resembled the molecular weight $(55000 \mathrm{Da})$ of the Endoglucanase (Arja, 2004). The molecular weight of the active cellulases produced by diverse fungal species varies between $12 \mathrm{kDa}$ and $126 \mathrm{kDa}$ (Bai et al., 2013). The molecular weight (50
$\mathrm{kDa}$ ) of the purified cellulase produced by Aspergillus unguis falls in this range. SDSpolyacrylamide gel electrophoresis (SDSPAGE) is the most commonly used method for determining the exact molecular weight of the diverse microbial enzymes (Joo et al., 2010, Lee et al., 2010 \& Ramani et al., 2012). Fungal cellulases are either monomeric (Naika et al., 2007) or dimeric (Chaabouni et al., 2005) in nature. Cellulase produced by Trichoderma viride was purified to homogeneity using DEAE-Sepharose column and the molecular weight was determined as 87 $\mathrm{kDa}$ by SDS-PAGE (Yasmin et al., 2013). Molecular weight of the monomeric cellulase produced by Penicillium pinophilum MS 20 was $42 \mathrm{kDa}$ and a single band was visible on SDS- PAGE gel (Pol et al., 2012). Strain Aspergillus awamori VTCC - F099 produced monomeric thermostable cellulase which appeared as a single band on SDS-PAGE gel with the molecular weight of $32 \mathrm{kDa}$ (Van Tuan Nguyen et al., 2010). In all the above mentioned research studies including ours, the purified cellulase formed a single band on the SDS-PAGE gel. This led to a conclusion that most of the fungal cellulases are active as monomers or homodimers and they migrate through the SDS-PAGE gel based on their molecular weight (Coral et al., 2002).

Purified cellulase enzyme obtained from Aspergillus unguis showed significantly higher activity at $70^{\circ} \mathrm{C}$ and at $\mathrm{pH} 5.0$ than the other tested conditions. Characterization revealed that the purified cellulose enzyme produced by Aspergillus unguis was optimally active at acidic $\mathrm{pH}$ and thermostable conditions. This purified cellulase showed optimum activity at $70^{\circ} \mathrm{C}$, indicating it is more stable at $70^{\circ} \mathrm{C}$ than any the other tested temperatures. Purified cellulase from Aspergillus sp was active and thermally stable at $\mathrm{pH} 7.0$ and $70^{\circ} \mathrm{C}$ (Anwaret et al., 2014). A filamentous fungus Trichoderma harzianum, produced cellulose degrading enzymes at $28^{\circ} \mathrm{C}$ 
(Bashir, 2009) and pH 5.5 (Sibtain et al., 2009). Purified cellulase from Aspergillus niger showed maximum stable activity at $45^{\circ} \mathrm{C}$ (Hurst et al.,1997). The purified cellulase from Trichoderma viride showed its optimum activity at $50^{\circ} \mathrm{C}$ (Abdul Sattar et al., 2014). Most cellulases from fungi are mesophilic, and the half-life of endoglucanase activity is typically less than 2 hours at $60^{\circ} \mathrm{C}$ (Batt, 2000). Aspergillus fumigatus that was isolated from hyperthermal compost, showed significantly higher thermostability at $70^{\circ} \mathrm{C}$ after 15 hours than the other temperatures (Liu et al., 2010). b-Glucosidase from Penicillium citrinum showed an optimum temperature of $70^{\circ} \mathrm{C}$, but its half life was 2 hours at $58^{\circ} \mathrm{C}(\mathrm{Ng}$ et al., 2010).

Based on the above literature and the results obtained in this study, it could be concluded that the purified cellulase from Aspergillus unguis is significantly functional under moderately acidic media conditions than the alkaline environments tested. This pure cellulase enzyme retained $25.5 \%$ of its original activity at $70^{\circ} \mathrm{C}$ for one hour and the capacity to retain the original activity slowly and steadily reduced with the time. The decrease in the activities of purified cellulase at the extreme acidic and alkaline $\mathrm{pH}$ values and higher temperatures might be due to the breakdown of the active site of the enzyme. Extreme alkaline $\mathrm{pH}$ might cause changes in the secondary and the tertiary structure of the cellulase structural proteins. The enzymes especially cellulases that are stable at acidic $\mathrm{pH}$ and high temperatures have great potential for the application in biotechnology (Mohanappriya and Kapilan, 2018). These are the important properties that are considered to be highly wanted for the industrial saccharification of cellulose containing natural sources. The influence of $\mathrm{pH}$ and/or temperature on the enzymatic hydrolysis of cellulose within the selected range in this study is very small, therefore this cellulase enzyme could be a choice for industrial usage.
The Michaelis-Menten Constant $(\mathrm{Km})$ is defined as the substrate concentration at half of the maximum velocity Vmax. Both kinetic parameters $\left(\mathrm{Km}=4.45 \times 10^{-2}\right.$ moldm ${ }^{-3}$ and $\mathrm{Vmax}=28.5714 \mathrm{mgml}^{-2}$ mins $^{-}$ ${ }^{1}$ at $\mathrm{pH} 5.0$ and $70^{\circ} \mathrm{C}$ ) of purified cellulase from Aspergillus unguis were determined by Lineweaver-Burk Plot for the cellulose substrate. Purified cellulases of different fungal and bacterial species show diversity in their $\mathrm{Km}$ and Vmax values. The $\mathrm{Km}$ and Vmax values of cellulase from A. anitratus and Branhamella sp. were $4.97 \mathrm{mM}$ and $7.90 \mathrm{mg} / \mathrm{mL}$ respectively for carboxymethyl cellulose (Ekperigin, 2007) while the Km and Vmax values of cellulase from Pseudomonas fluorescens were 3.6 $\mathrm{mg} / \mathrm{mL}$ and $1.1 \mathrm{mM}$ (Bakare et al., 2005). The difference in $\mathrm{Km}$ and Vmax values of the purified cellulase from Aspergillus unguis and other fungal species may be due to the difference in the genetic constitution of the fungal species concerned and the degree of adaptation potential to the culturing environment (Iqbal et al., 2011).

\section{CONCLUSION}

The crude cellulase enzyme from Aspergillus unguis was purified from the spent medium by $80 \%$ saturated ammonium sulphate precipitation and by ion exchange chromatography using DEAE-sepharose fast flow and the molecular weight was determined as 50 KDa. Purified cellulase showed zero order kinetics for 5 minutes. The $\mathrm{pH}$ and temperature optimum for the purified cellulase were 5.0 and $70^{\circ} \mathrm{C}$ respectively. Michaelis constant for the pure cellulase to soluble cellulose was $4.45 \times 10^{-2} \mathrm{moldm}^{-3}$ and Vmax was $28.5714 \mathrm{mg} \mathrm{ml}^{-2} \mathrm{mins}^{-1}$ at $\mathrm{pH}$ 5.0 and at $70^{\circ} \mathrm{C}$. Since the purified cellulase from Aspergillus unguis was active in moderately acidic $\mathrm{pH}$ (5.0) and showed better stability at $70^{\circ} \mathrm{C}$ it could be considered as a potential candidate for the conversion of biomass into fuel and other industrial applications. 


\section{Acknowledgements}

The authors express sincere gratitude for the University of Jaffna Research Grant 2016.

\section{REFERENCES}

Ahmed, S., Bashir, A., Saleem, H., Saadia, M. and Jamil, A. (2009). Production and purification of cellulosedegrading enzymes from a filamentous fungus Trichoderma harzianum. Journal of biological science.;41:1411-1419.

Arja, M.O. (2004). Trichoderma reesei strains for production of cellulases for textile industry.VTT publications.550.

Bagga, P.S., Sandhu, D.K., Sharma, S (1990). Purification and characterization of cellulolytic enzymes produced by Aspergillus nidulans, Journal of applied Microbiology, 68(1):61-68.

Bakare, M.K., Adewale, I.O., Ajay, A., Shonukan, O.O. (2005). Purification and characterization of cellulase from the wildtype and two improved mutants of Pseudomonas fluorescens. Afri $J$ Biotechnol. 4:898-904.

Bai, H., Wang, H., Sun, J., Irfan, M., Han, M. (2013). Production, purification and characterization of novel beta glucosidase from newly isolated Penicillium simplicissimum $\mathrm{H}-11$ in submerged fermentation. EXCLI J. 12: 528-540.

Bhat, M. (2000). Cellulases and related enzymes in biotechnology. Biotechnol Adv.18:355.

Chaabouni, S.E., Mechichi, T., Limam, F., Marzouki, N. (2005). Purification and characterization of two low molecular weight endoglucanases produced by Penicillium occitanis mutant Pol 6. Appl Biochem Biotechnol. 125:99-112.
Coral, G., Arikan, B., Ünlandi, M.N., Guvenmez, H. (2002). Some properties of crude carboxymethyl cellulase of Aspergillus niger Z10 wild-type strain. TJB;26: 209-213.

Gaur, R., Tiwari, S. (2015). Isolation, production, purification and characterization of an organic-solventthermostable alkalophilic cellulase from Bacillus vallismortis RG-07. BMC Biotechnology.15-19.

Ghose, T.K. (1987). Measurement of cellulase activities. International union of pure and applied chemistry.;59:257-268.

Harrison, M.J., (1987). Nouwens, A.S., Jardine, D.R., Zachara, N.E., Gooley, A.A., Nevalainen, H., et al. Modified glycosylation of cellobiohydrolase I from a high cellulase-producing mutant strain of Trichoderma reesei. European J Biochem. 1998; 256: 119-27.

Ijaz, A., Anwar, Z., Irshad, M., Iqbal, Z., Arshad, M., Jave, M., Zulfiqar, M., Rehman, A.A. and Ahmad, A. (2014). Purification and Kinetic Characterization of Statistically Optimized Cellulase Produced from Aspergillus niger. Romanian Biotechnological Letters. 19.

Iqbal, H.M.N., Ahmed, I., Zia, M.A., Irfan, M. (2011). Purification and characterization of the Kinetics parameters of cellulase produced from wheat straw by Trichoderma viride under SSF and its detergent compatibility. Adv. Biosc. Biotechnol.; 2:149-156.

Joo, A.R., Jeya, M., Lee, K.M., Lee, K.M., Moon, H.J. (2011). Production and characterization of $\beta$-1, 4-glucosidase from a strain of Penicillium pinophilum. Process Biochemistry. 2010;45:851-858.

Juturu, V. and Wu, J. (2014). Microbial cellulases: Engineering, production and 
applications. Renew Sust Energ Rev.;33:188-203.

Kapilan, R. and Arasaratnam, V. (2014). Purification of xylanase produced by Bacillus pumilu. Journal of National Science foundation of Sri Lanka. 42:365368.

Lee, K.M, Jeya, M., Joo, A.R, Singh, R., Kim, I.W. (2010). Purification and characterization of a thermostable endo- $\beta$ 1, 4-glucanase from a novel strain of Penicillium purpurogenum. Enzyme and Microbial Technology.;46:206-211.

Liu, D., Zhang, R., Yang, X., Wu, H., Xu, D, Tang, Z. (2011). Thermostable cellulase production of Aspergillus fumigatus Z5 under solid-state fermentation and its application in degradation of agricultural wastes. Int Biodeter Biodegr.;717.

Lowry, O.H., Rosenburg, N.J., Farr, A.L., Randall, R.J. (1951). Protein measurement with the Folin phenol reagent. Journal of Biological Chemistry.;193:265-275.

Lynd, L.R., Weimer, P.J., Zyl, W.H., Isak, S. (2002). Microbial cellulose utilization: Fundamentals and biotechnology microbiology. Mole Biol Reviews.;66:506.

Mathew, G.M., Sukumaran, R.K., Singhania, R.R., Pandey, A. (2008). Progress in research on fungal cellulases for lignocellulose degradation. JSIR.;67: 898.

Mehrotra, R. and Aneja, K. (1990), An introduction to mycology: New Age International.

Miller, G.L. (1959). Use of Dinitrosalicylic acid reagent for determination of reducing sugar. Analytical chem.;31:426-428.

Mohanappriya, S. and Kapilan, R., (2018). Isolation of efficient cellulase producing Aspergillus unguis UCSC324 and determination of the kinetic properties of its crude cellulase. AGRIEAST: Journal of Agricultural Sciences, 12(2):35-48.

Moore Landecker E. (1996). Fundamentals of the Fungi. ( $4^{\text {th }}$ edn) New Jersey: Prentice Hall, inc.

Murray, P., Aro, N., Collins, C., Grassick, A., Penttilä, M. (2004). Expression in Trichoderma reese $i$ and characterisation of a thermostable family $3 \beta$-glucosidase from the moderately thermophilic fungus Talaromyces emersonii. PEP.;38:248-257.

Naika, G.S., Kaul, P., Prakash, V. (2007). Purification and characterization of a new endoglucanase from Aspergillus aculeatus. J Agric Food Chem.;55:7566-7572.

Ng, I., Li, C.W. and Chan, S.P. (2010). High-level production of a thermoacidophilic b-glucosidase from Penicillium citrinum YS40-5 by solid-state fermentation with rice bran. Bioresour Technol.;1310.

Picart, P., Diaz, P., and Pastor, F.I. (2007). Cellulases from two Penicillium sp. strains isolated from subtropical forest soil: production and characterization. Lett Appl Microbiol; 45:108-113.

Development Core Team. R. (2010). A Language and Environment for Statistical Computing. R Foundation for Statistical Computing, Vienna, Austria. http://www.R-project.org/.

Ramani, G., Meera, B., Vanitha, C., Rao, M., and Gunasekaran, P. (2012). Production, purification, and characterization of a $\hat{\mathbf{I}}^{2}$-glucosidase of Penicillium funiculosum NCL1. Appl Biochem Biotechnol;167:959-972.

Sattar, J.A., Alaa, J.T. and Zeena, G. (2014). Purification and kinetic study on cellulase Produced by local Trichoderma viride,Journal of Advances in Chemical 
Engg., \& Biological Sciences.;1:23491515.

Singhania, R.R., Sukumaran, R.K., Pillai, A., Prema, P., and Szakacs, G. (2006). Solid-state fermentation of lignocellulosic substrates for cellulase production by Trichoderma reesei NRRL 11460. Indian journal of Biotechnology.5:332-336.

Sohail, M., Siddiqi, R., Ahmad, A., Khan, S.A. (1997). Purification and properties of a cellulase from Aspergillus niger. Biochemical Journal.;165:33-41.

Van Tuan Nguyen DTQ. (2010). Purification and properties of a novel thermoactive endoglucanase from Aspergillus awamori VTCC-F099. Australian Journal of Basic and Applied Sciences. 4:6211-6216.

Yasmin, S., Mattoo, R., Nehvi, F. (2013). Isolation, characterization and molecular weight determination of cellulase from Trichoderma viride. African Journal of Biotechnology.;12:4503-4511.

Zaldivar, J., Nielsen, J., Olsson, L. (2001). Fuel ethanol production from lignocellulose: a challenge for metabolic engineering and process integration. Appl Microbiol Biotechnol. ;56:17-34. 